Historic, Archive Document

Do not assume content reflects current scientific knowledge, policies, or practices. 


\section{Contract Prices}

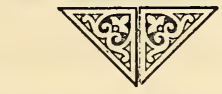

L

If

+ FEB 31930 .

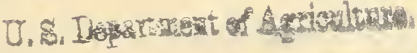

FOR STRICTLY

HIGH GRADE

SEEDS

Selected From Carefully Grown Crops By

THE KIMBERLIN SEED COMPANY

SAN JOSE $\quad \cdots \quad$ CALIFORNIA

Vegetable Seed Trials 


\begin{tabular}{|c|c|c|}
\hline Quantity & V A R I E T Y & Price \\
\hline & BEET & \\
\hline & urosuy s meyplial & \\
\hline & Early Blood Turnip.... & \\
\hline & Early Wonder......... & \\
\hline & Eclipse & \\
\hline & Extra Early Flat Egyptian... & \\
\hline & $\begin{array}{l}\text { SWISS CHARD } \\
\text { Large White Ribbed }\end{array}$ & \\
\hline & Lucullus.... & \\
\hline & CARROT & \\
\hline & Chantenay.................... & \\
\hline & Danvers Half Long.. & \\
\hline & Early Scarlet Horn.... & \\
\hline & French Forcing... & \\
\hline & Hutchinson..... & \\
\hline & Long Orange.... & \\
\hline & Oxheart.... & \\
\hline & Scarlet Nantes, stump rooted & \\
\hline & St. Valery.... & \\
\hline & White Belgian... & \\
\hline & CELERY & \\
\hline & Golden Self Blanching & \\
\hline & Henderson's Easy Blanching & \\
\hline & White Plume.. & \\
\hline & Winter Queen... & \\
\hline & ENDIVE & \\
\hline & Broad Leaved Batavian. & \\
\hline & Green Curled Ruffec & \\
\hline & Moss Curled.................... & \\
\hline & Pancalier........... & \\
\hline
\end{tabular}




\begin{tabular}{|c|c|c|}
\hline Quantity & V A R I E T Y & Price \\
\hline & LETTUCE & \\
\hline & All Season...................... & 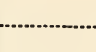 \\
\hline & All the Year Round.. & \\
\hline & Balloon Cos... & \\
\hline & Big Boston, W. S... & \\
\hline & Big Boston, B. S.... & \\
\hline & Black Seeded Simpson... & \\
\hline & Black Seeded Tennisball... & \\
\hline & Boston Curled............ & \\
\hline & California Cream Butter.. & \\
\hline & Crisp as Ice..... & \\
\hline & Denver Market........ & \\
\hline & Drumhead or Malta.. & \\
\hline & Early Curled Silesia... & \\
\hline & Early Curled Simpson... & \\
\hline & Grand Kapias... & \\
\hline & Hanson Improved. & \\
\hline & Hubbard Market...... & \\
\hline & Iceberg........... & \\
\hline & Mammoth Black Seed Butter & \\
\hline & New York & \\
\hline & Prizehead.... & \\
\hline & Salamander.... & \\
\hline & Tomhannock.. & \\
\hline & Trianon Cos.... & \\
\hline & Unrivalled... & \\
\hline & Wayahead..... & \\
\hline & White Paris Cos.... & \\
\hline & White Seeded Tennisball... & \\
\hline & White Summer Cabbage... & \\
\hline
\end{tabular}




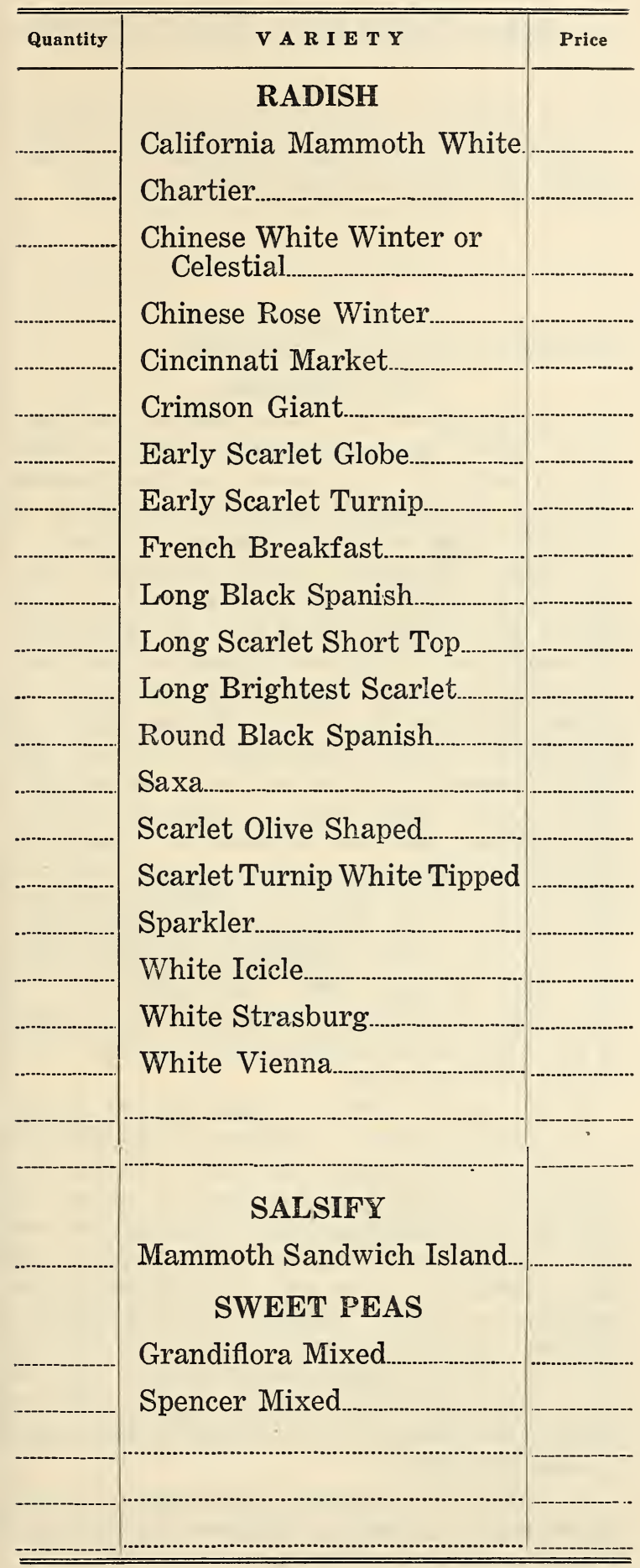


Thits A Anremment Made in duplicate

on

19

by and between THE KIMBERLIN SEED COMPANY, Seed Growers of San Jose, California, hereinafter called the Seller, and.

of

hereinafter called the Purchaser.

\section{WITNESSETH:}

1. Seller agrees to sell and deliver and Purchaser agrees to accept and pay for the varieties of seeds in the amounts, at the prices as set forth in attached pages, and subject to the terms and conditions herein provided.

2. Seller agrees to plant, or cause to be planted, during the season of 19........, an acreage of land which will produce, under normal conditions, an amount of seed of the varities herein named which will be sufficient to enable the Seller to deliver the quantities of the seeds herein contracted for; and the Seller agrees to deliver as soon as possible after harvest, such seeds in good merchantable condition, as herein defined, F. O. B. growing station, containers extra at cost, and not returnable. The term "in good merchantable condition" is defined as seeds properly cleaned for seeding purposes, approximately free from foreign seeds distinguishable by their appearance and of a germination equal to the fair average germination of the crop of the current year.

3. In case of partial or total failure of any or all crops planted, or caused to be planted by the Seller for the purpose of producing the varieties of seeds herein named, or, in case of damage to, or destruction of the Seller's seed stocks before planting, or to the products of such plantings, or to any seed through fire, accident or other casualty beyond Seller's control, the Seller shall be obliged to deliver, if at all, proportional quantities only, and, in any event, the Seller shall have the right to reserve an amount of seed equal to that used in said planting.

4. Purchaser shall make payment for seeds delivered, by a trade acceptance due and pay- 
able net 60 days from date of shipment, or by cash within 30 days from date of shipment, less a discount of $11 / 2 \%$. Purchaser shall pay interest at the rate of $7 \%$ per annum on any overdue payments of purchase price.

If, at any time, the financial condition of the Purchaser becomes unsatisfactory to the Seller, the Purchaser agrees, upon receipt of written notice to that effect, and upon demand of the Seller, to pay for the seeds in advance of shipment, less a cash discount of $11 / 2 \%$, and if such payment is not made within ten (10) days from the receipt of such demand for payment, this agreement shall thereupon be deemed to be breached by the Purchaser.

5. Except as herein otherwise expressly provided, the Seller gives no undertaking or warranty express or implied, as to description, quality, productiveness, or any other matter of any seeds sold by it and will not be in any way responsible for the crop.

6. Purchaser's claims for shortages of deliveries must be made to Seller immediately on receipt of shipment and all germination tests must be made and reported in writing (including telegram) by Purchaser to Seller within 15 days after receipt ot shipment.

IN WITNESS WHEREOF, the parties have hereunto set their hands on the day and year first above written.

The Seller

By

The Purchaser

By 


\section{CONTRACT}

THE KIMBERLIN SEED COMPANY

of San Jose, California

With

Address

Date

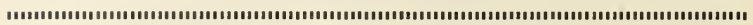
|",

\section{LETTUCE}

All our stocks of lettuce are produced from individual plant selection, and we believe our stocks are as fine as any grown in the United States.

\section{ONION}

Our onion seed is produced from carefully selected bulbs, true to type and color.

\section{CARROT}

Our carrot seed is produced from European stocks carefully selected. Like the lettuce, we are developing this from individual plant selection.

Besides varieties of garden seed listed, we are prepared to grow from customers' private stocks and will give special attention to such orders.

Contracts are all subject to crop conditions. In case of failure all orders are filled pro rata.

Terms: Our terms are sixty day acceptance, or $11 / 2$ per cent discount for cash inside of thirty days from date of invoice. F. O. B. our growing station. Bags at market value and not subject to discount. 